\title{
Thinking through our Sisters Acting through their Words
}

\author{
Marta Correia \\ ILCML /CETAPS, University of Porto
}

\begin{abstract}
This paper aims to demonstrate some points in common between Virginia Woolf's ideas expounded in Three Guineas (1938) and the words of the Three Marias in New Portuguese Letters (1972) in order to reflect on their validity in today's world. The themes of war, institutionalised discrimination against women and the general acceptance of systems of oppression will be addressed. Adopting a method Woolf herself used in her essay, I will refer to current newspaper stories, "history in the raw" (Woolf 2008: 159) to show how the world has/has not changed since these two pieces of work were published and how both can still be used to comment on reality in the $21^{\text {st }}$ century in England, Portugal and other parts of the world as well. I will also refer to the work of Women in Black Belgrade, a group of Balkan activists born out of the war in the former Yugoslavia in 1991 and still at work today. Their work is used as the ultimate example of the need to think through our sisters, women writers, observers and critics of their society to reassess our own world today, to take responsibility and, thus, be better equipped to take action and operate change.
\end{abstract}

Keywords: Virginia Woolf, Three Guineas, Three Marias, New Portuguese Letters, Women in Black Belgrade

Resumo: Este trabalho pretende identificar pontos em comum entre as ideias expostas por Virginia Woolf em Três Guinéus (1938) e as palavras das Três Marias em Novas Cartas Portuguesas (1972) com o intuito de reflectir sobre a validade destas obras no mundo de hoje. Os temas da guerra, da discriminação institucionalizada contra as mulheres e a aceitação generalizada de sistemas de opressão serão referidos. Adotando uma metodologia que Woolf utilizou no seu ensaio, recorrerei a artigos de jornal dos nossos dias, "a história crua" (Woolf 2008: 159) para perceber em que medida o mundo mudou ou não desde a publicação 
destas obras e para compreender como estas podem ser usadas para comentar a realidade do século XXI na Grã-Bretanha, em Portugal e noutros lugares. Irei também referir o trabalho das Mulheres de Negro de Belgrado, um grupo de activistas contemporâneas dos balcãs, nascido do conflito na ex-Jugoslávia em 1991.0 seu trabalho é o exemplo claro da necessidade de pensarmos através das nossas irmãs, mulheres escritoras, observadoras e críticas da sociedade para reavaliarmos o mundo de hoje, assumirmos responsabilidade e, assim, estarmos bem equipadas para agir e mudar o estado de coisas.

Palavras-chave: Virginia Woolf, Três Guinéus, Três Marias, Novas Cartas Portuguesas, Mulheres de Negro Belgrado

Or rather: what can words do?

\author{
Maria Isabel Barreno \\ Maria Teresa Horta \\ Maria Velho da Costa
}

\title{
Introduction
}

When Virginia Woolf wrote Three Guineas in 1938, the world that surrounded her was violent, menacing and oppressive. Having lived through the horror of the First World War, Woolf now experienced the social consequences of the Great Depression, the rise of Fascism and National-Socialism in Europe, the threat of an impending second world conflict and the personal loss of having her nephew Julian killed in the Spanish Civil War. Woolf wrote her essay out of a desperate need to point out the grave errors on which the society she lived in was based: "It has pressed and spurted out of me (...) like a physical volcano. And my brain feels cool and quiet after the expulsion" (Woolf 1985:112). It is clear from these words written in her diary the sense of relief Woolf felt after finishing the work she had seething inside her. Three Guineas would be her most controversial work and, although not banned, it was snubbed and attacked by many. The tone used, the issues addressed and the imagery it contains all contribute to a piece of writing which has been perceived as 
"cantankerous", resentful and a mere "series of complaints."1 E.M. Forster went as far as to say that, "In the 1940s I think she had not much to complain of and kept on grumbling from habit" (apud Marcus 1978: 94). Virginia Woolf was not just grumbling; she was crossing a line and revealing injustices in a patriarchal regime she viewed as dictatorial.

Thirty-four years later in a different European country, the Three Marias wrote New Portuguese Letters; they lived under a fascist regime, and their country was involved in a colonial war with devastating consequences for all parties. Their work delves into numerous themes of contemporary interest, such as the unequal manner in which their society is organised, violence imposed on both women and men, the feminisation of poverty, emigration, among others. The reception to their book proves they too crossed the line of what was expected from women. The first edition was apprehended and destroyed by government censorship officials after three days on the market, the authors interrogated by the regime secret services and sued for writing a book described as "irremediably pornographic (...) and offensive to public morals". 2 These are certainly signs that the Portuguese writers ventured into a sphere that was not theirs, confronted sacrosanct spaces of patriarchal power, exposed and defied them.

\section{Thinking through our sisters}

The doors seemed to have been opened as society had changed in the years prior to the publication of Three Guineas with the introduction of women's right to vote, although limited, in 1918 and in 1919 with the Sex Disqualification Act, which admitted women to the civil service and allowed them to obtain qualifications at Universities. Figures cited in Woolf's essay show, however, women's wages were lower than men's and the number of women participating in public life was almost irrelevant, facts which lead to one of the conclusions in Three Guineas: "The doors are still locked, or at best ajar" (Woolf 2008: 181). If we use the strategy Virginia Woolf used when writing her essay and look at the press today, "history in the raw" (idem: 159), as Woolf described it herself, it is then fair to say that doors are still not fully open to women, judging by reports in newspapers. In October 2013 The Guardian reported the results of a recent survey that women occupy 1 in 8 top 
roles in the City of London and that those women who do reach senior positions are in jobs that are traditionally lower paid. Público reported in February of that same year that women in Portugal need to work 59 more days to earn the same amount as men. ${ }^{3}$ The words of the female writers in question have not ceased to be valid in today's world.

The doors may seem to be fully open but women are clearly not going through them as freely as would be expected. Pierre Bourdieu warns that "the visible changes that have affected the condition of women mask the permanence of the invisible structures" (2001: 106). These invisible structures are the ones we need to identify in order to dismantle them. Woolf and the Three Marias set out to do just that and the reaction to their words is, unsurprisingly, of shock and repudiation from the part of those who maintain the status quo.

Michel Foucault recognises the insidious nature of power, which he defends "is a productive network which runs through the whole social body (...) power means relations, a more-or-less organised, hierarchical, co-ordinated cluster of relations (...) but operated from above" in "the form of a chain (...) exercised through a net-like organisation" (1980: $98,118,198,200)$. If one is not aware of how the dissemination of power works, the fact that it permeates all aspects of society and the relations within it, how are we to challenge it? In his seminal book Masculine Domination, Bourdieu maintains that "the eternalization of the structure of sexual division (is) performed by interconnected institutions such as the family, the church, the state, the educational system" (2001: viii). Virginia Woolf identifies the very same institutions which need reform and includes in Three Guineas printed photographs of officials who are responsible for the society she lives in, incapable of preventing war, unwilling to allow women a full participation in the public sphere.

In New Portuguese Letters references to the status of women abound and it is claimed, "We are offered no other alternative save outright war against the whole social system (...) and are forced to destroy everything" (1975: 329, 330). ${ }^{4}$ Virginia Woolf too resorts to metaphorical fires to destroy the old system; words, traditional schools are set alight in her work. Characters, women, men and even children compose throughout New Portuguese Letters the image of the perfect woman desired by the regime: docile, obedient, 
quiet, beautiful, caring, whose main duty is to have children and look after the home and the family. This is the image of the Angel in the House, a representation of the ideal woman brought up to perform an "unpaid-for profession" (Woolf 2008: 267) called marriage, as Virginia Woolf described it in the 1930s, and a spectral intruder who women have to fight against in order to be independent. 5

Institutions dominate women through a range of strategies, one of them being the control of their bodies revealed in the laws of the land through, for example, the prohibition of abortion, as well as the leniency towards the perpetrators of domestic violence. The direct quote in the work of the Three Marias of the Portuguese Penal Code in place at the time shows the different treatment it reserved for adulterous husbands and wives which brings the text to the following conclusion: "we will always be objects as unmarried women subject to the will of our parents so long as we are minors, and after we have married, to the will of our husbands" (1975: 332). ${ }^{6}$

Today abortion is legal in Portugal up to 10 weeks after conception ${ }^{7}$ and women and men are, in principle, treated equally in the eyes of the law. Nevertheless, even though laws have changed, the ingrained mentality which views women as possessions and a colonial space of men, as the three Portuguese writers would say, remains. Statistics reported in the newspaper Diário de Notícias in November 2015 reveal that during the year up to that date, 27 women were fatal victims of domestic violence and that 33 more survived attempted murder perpetrated by their partners or former partners. The same article also defines this type of violence as a European problem, citing figures published by the European Union Agency for Fundamental Rights in which 39\% of women in the European Union knows of a case of domestic violence in their family or social circle. ${ }^{8}$ The Guardian reported in January 2016 that, according to a study carried out by the Crime Survey for England and Wales (CSEW) there has been an increase in the violence against women, including domestic abuse, since 2009.9 In December 2013 this same newspaper reported figures from the CSEW that reveal that 1 in 3 women have experienced some kind of domestic abuse since the age of 16.10 
What is more, as primary carers of society, women are to this day the weakest link in a society that expects them to care for its children and elderly. Both in Portugal and in England women are identified as the group that has been hit the hardest by the recession. The Guardian reported in January 2014 that the high cost of childcare is a barrier for employment for women ${ }^{11}$ and in February 2015 that childcare costs have increased 4.1\% the previous year. ${ }^{12}$ Público reported in January 2014 the results of a study conducted by AMI, a Portuguese NGO, which reveals the typical profile of Portuguese poverty: a middleaged woman with a very low level of education. Boaventura Sousa Santos is of the opinion, as stated in his regular column in the weekly magazine Visão in May 2012, that one of the perverse effects of the financial crisis is to reduce women to the "unpaid-for profession" of looking after their families under the cover of a discourse that encourages the virtuous role of women. He also points out that the female population is still subject to, amongst other things, blockade to the public sphere and access to political life. ${ }^{13}$ At the beginning of 2016 the representation of women in public office in England was still an issue: out of a total of twenty-two cabinet ministers of the Conservative party only seven are women. The situation has improved slightly since July, as the Prime Minister is now a woman, the second woman to have ever occupied such a position in the United Kingdom. However, there are still only seven women cabinet ministers out of a total of twenty-seven. The state of affairs in Portugal is similar: only 4 women in a Socialist Party cabinet of seventeen ministers.

\section{Acting through their words}

Surprisingly, or maybe not so, Women in Black Belgrade, a group of Balkan activists born out of the war in the former Yugoslavia in 1991 and currently still at work, base their activities on the fight against the institutions Virginia Woolf denounced as being responsible for the state of affairs in the 1930s in England and that the activists recognise as being accountable for the recent history in the Western Balkans. Three Guineas is included in Women in Black Belgrade's list of publications, as it was translated by the activists to make its reading more easily accessible to local readers (Zajović 2006:70). 
Woolf's seminal essay is also frequently referenced in their written work (Zajović 2013: 20, 110, 201). Through their educated activism they articulate feminism and anti-militarism not in the sense that women are natural pacifists, a notion they reject, but because the male dominated institutions in Serbia and a patriarchal system deny women a full participation in public life, limit them to the role of mothers and carers of society. During the war women were victims of mass rape in the name of nationalism and also urged by the government and the Orthodox church to produce ethnically superior Serbian nationals. ${ }^{14}$ These women witnessed first-hand the insanity of extreme violence perpetrated by a patriarchal/dictatorial regime and are still fighting the institutions that rule Serbia today. They still monitor trials and denounce cases of leniency towards war criminals (Zajović 2006: 74, 75);15 they organise educational workshops (idem: 51) to promote a system which would, in the words of Virginia Woolf, "produce civilised human beings capable of preventing war" (Woolf 2008: 262); they remind the government that massacres such as Srebrenica must be officially marked so that they are remembered as mistakes that must not be repeated (Zajović 2006: 50). Also, in defiance of a government that views Conscientious Objection as shameful, Women in Black staged a street action where they produced a live monument entitled "In memory of the deserters" (Zajović 2013:99). These women are an example of how an alternative world can be delineated and put into practice...eventually.

Three Guineas is haunted by constant references to pictures of extreme violence taken in the battlefield of the Spanish Civil War: they "are all this time piling up (...) photographs of more dead bodies, of more ruined houses" (Woolf 2008: 210); as time passes, as the essay unfolds more and more photographs come into play, more and more people become victims of war, it is as if the bodies are piling up as well. And so they are. The pictures have not ceased to pile up to this day, nor have the bodies. It has been 78 years since the publication of Three Guineas and, as Woolf herself remarked, "The human race seems to repeat itself insufferably" (Woolf 1994: 464).

In 1972, when New Portuguese Letters was published, Portugal contributed to the "photographs of dead bodies and ruined houses" with a colonial war between 1961 and 
1974 on three fronts. In 1995 Women in Black witnessed genocide in Srebrenica and the generalised destruction of life in the territories of the former Yugoslavia. All around the world there are still "photographs of dead bodies and ruined houses." The photographs have not ceased to pile up to this day. I dare you to open the newspapers today.

We are all too familiar with these "photographs of dead bodies and ruined houses" and the devastating effects that armed conflicts bring to everyday life. Men return traumatised from war and, as one of the characters tells her employer from New Portuguese Letters: "ever since he came back from the wars everything is all mixed up in his head and I'm frightened of him, he shouts night and day, he beats me" (1975: 224). ${ }^{16}$ Septimus Smith, a character in Woolf's Mrs Dalloway, is a First World War veteran reduced to a casualty who would today most likely be diagnosed with PTSD (Post-traumatic stress disorder). Men incapable of dealing with their experiences, unadjusted to life back in their safe homes, behaving violently towards their wives, leading them to despair. And these are not fictional problems. Women in Black Belgrade activists, many of whom lived through the worst atrocities committed in Europe since the Second World War, note such issues in their activity reports and denounce how the government sends young men to wars and is then incapable of dealing with their physical and mental injuries and the social consequences of such ailments (Zajović 2013: 129, 130).

Women in Black Belgrade were, at the time of the war, active in publicly protesting against the regime and protecting deserters; in their 2013 report they reiterated their support for, "the men who refused to participate in all military formations (...) in the aggressor army as well as in the armies of the aggressed countries" (Zajović 2013: 96). During the conflict, they founded a Safe House for deserters in Budapest, Hungary, where men hid to escape from conscription to the Serbian military (Zajović 2006: 64). These acts of civil disobedience reflect the belief that it is necessary to confront the regime, openly defend the refusal to conform and cooperate with a government they deem criminal, and support those who disobey it to achieve a fairer society.

The ultimate aim of Three Guineas is to answer a question posed by a man to the female narrator: "How are we to prevent war?" (Woolf 2008: 153) and it becomes clear that 
the stance defended is one of pacifism and refusal of any form of oppression which limits women, but also men since one of the crucial ideas of the text is the identification of the figure of the patriarch with that of the dictator:

The whole iniquity of dictatorship, whether in Oxford or Cambridge, in Whitehall or Downing Street, against Jews or against women, in England, or in Germany, in Italy or in Spain is now apparent to you. But now we are fighting together. (idem: 304)

The ultimate answer in Three Guineas is that peace will only exist when education produces civilised human beings, not just men, not just women, capable of preventing war, who refuse to participate in or live under systems of oppression, that is, patriarchy and/or dictatorship.

\section{Conclusion}

I ask, using the words of the Three Marias: "But what can literature do? Or rather: what can words do?" (Barreno / Horta / Costa 1975: 266). ${ }^{17}$ Literature records memory, denounces, educates, spreads concerns and alternatives. Literature can be an act of civil disobedience which confronts and questions the status quo. Words shout out solutions and, if ignored or dismissed, they need to be insistently repeated. Literature informs and inspires real people to take action and this is why we still read works such as Three Guineas and New Portuguese Letters: to think through our sisters, a word I may have presumptuously, but consciously chosen for this paper, a lineage of women writers whose words ring contemporary, inform us and suit reality today. And even if this means uncovering a certain "odour" the word feminist suggests, as Virginia Woolf called the invisible forces of prejudice; even if it means being called, as the Three Marias predicted in their work, trouble-makers, lesbians or witches or any other random words meant as insults. We will keep thinking, we will keep writing, we will share the words we read as long as necessary in the hope that if they "who now agitate these humble pens may in another century or two speak from a pulpit" (Woolf 2008: 242). Challenging the institutions which perpetuate discrimination both openly and, insidiously, confronting them, 
denouncing them and demanding the need for alternatives is, I suspect, always going to be a confrontational act.

If we look around us, we will see that there are situations that cannot be tolerated and that eerily remind us of previous historical moments in which Woolf and the authors of New Portuguese Letters wrote: fascist movements are not obsolete in Europe today, inequality is not a problem of the past, nor is war or its human consequences, embodied by the wave of refugees seeking a safe haven in the old continent, living characters of similar pictures to the ones sitting on Woolf's table in 1938. Going against the grain causes friction, but friction, insistent friction can also cause the spark that ignites change. And bold words might do just that. May they inspire us to act.

\section{NOTES}

\footnotetext{
1 These were the opinions of E.M. Forster and Batchelor of Three Guineas (apud Silver 1991: 352, 356).

${ }^{2}$ http://www.novascartasnovas.com/en/index_en.html

3 http://www.publico.pt/sociedade/noticia/mulheres-europeias-trabalham-mais-59-dias-para-ganharem-o mesmo-que-os-homens

4 "Se outra alternativa não nos derem que a guerra aberta contra todo um sistema social (...) que tenhamos de destruir tudo" (Barreno / Horta / Costa 2010: 249).

5 "Professions for Women" is a speech given by Woolf to the London Branch of the National Society for Women's Service in 1931.

6 "Usadas sempre seremos como objectos, em solteiras entregues enquanto menores ao livre-arbítrio de nossos pais e depois de casadas, a nossos maridos" (Barreno / Horta / Costa 2010: 252). 
7 In England abortion is legal up to 24 weeks after conception.

8http://www.dn.pt/sociedade/interior/27-mulheres-mortas-neste-ano-quebre-o-silencio-4903091.html

${ }^{9} \mathrm{http}: / /$ www.theguardian.com/society/2016/jan/13/hidden-rise-violent-crime-growth-violence

10 http://www.theguardian.com/society/2013/dec/22/domestic-abuse-half-million-victims

${ }^{11}$ http://www.theguardian.com/money/2014/jan/23/cost-childcare-barrier-work-mothers-survey

12 http://www.theguardian.com/money/2015/feb/19/cost-childcare-high-uk-families-work-familychildcare-trust -nursery

${ }^{13}$ http://visao.sapo.pt/as-mulheres-a-crise-e-a-pos-crise=f662025

${ }^{14}$ The Croatian government and the Catholic Church displayed a parallel rhetoric by reducing women to their roles of producing pure Croats to fight against the Serb invaders.

15 The most recent case is that of Vojislav Šešelj, acquitted by the International Tribunal for the former Yugoslavia at The Hague and soon after elected as a member of the Serbian Parliament in April 2016.

16 "O meu António (...) desde que veio das guerras anda transtornado da cabeça e me mete medo grita noite e dia, bate-me" (Barreno / Horta / Costa 2010: 163).

17 "Mas o que pode a literatura? Ou antes: o que podem as palavras?" (Barreno / Horta / Costa 2010: 220). 


\section{Works cited}

Barreno, Maria Isabel / Maria Teresa Horta / Maria Velho da Costa (1975), New Portuguese Letters, translated by Helen R. Lane, New York, Doubleday \& Company, Inc. [1972].

-- (2010), Novas Cartas Portuguesas, Edição anotada, Organização de Ana Luísa Amaral, Lisboa, D. Quixote [1972].

Bourdieu, Pierre (2001), Masculine Domination, translated by Richard Nice, Stanford, Stanford University Press.

Foucault, Michel (1980), Power/Knowledge: Selected Interviews and other Writings: 19721977 (Colin Gordon ed.), New York, Pantheon Books.

Marcus, Jane (1978), “Art and Anger”, Feminist Studies, Vol. 4, no 1, February, 68-98.

Silver, Brenda R. (1991), “The Authority of Anger: 'Three Guineas as Case Study', Signs, Vol. 16, № 2, Winter, 340-370.

Woolf, Virginia (2008), A Room of One's Own and Three Guineas, Oxford, Oxford University Press.

-- (1994), Leave the Letters Till We're Dead: The Letters of Virginia Woolf 1936-1941 (Nigel Nicolson ed.) Volume VI, London, The Hogarth Press.

-- (2003), Mrs Dalloway, Hertfordshire, Wordsworth Editions.

-- (1985), The Diary of Virginia Woolf (Anne Olivier Bell ed.), Volume V, London, Penguin Books.

-- (2011), The Essays of Virginia Woolf, (Andrew MacNeillie ed.), Volume V, London, The Hogarth Press.

Zajović, Stanislava (ed.) (2006), Always Disobedient, translated by Kandice Arwood et al, Belgrade, Standard 2.

-- (ed.) (2013), Women for Peace, translated by Stanislava Lazarevi et al, Novi Sad, Art Print. 
Marta Correia is currently attending a PhD course in Feminist Studies at the Faculty of Arts and Humanities at the University of Porto. She holds an M.A. degree in Women's Studies. Her main interests in research include Virginia Woolf and her facet as a feminist, women's activist groups, female writers who focus on the issues of oppression and war, and also food in times of armed conflict through the eyes of women writers. At the moment, she is researching the work of Slavenka Drakulić, a Croatian author who has dedicated some of her writings to the conflict in the former Yugoslavia. Marta has participated in a number of projects at the University of Porto coordinated by CETAPS (the Centre for English, Translation and Anglo-Portuguese Studies) and ILCML (Instituto de Literatura Comparada Margarida Losa), and several international conferences in Portugal and abroad. 